\title{
VIII. A geometrical proposition
}

\section{James Thomson LL.D.}

To cite this article: James Thomson LL.D. (1839) VIII. A geometrical proposition, Philosophical Magazine Series 3, 15:93, 41-42, DOI: 10.1080/14786443908649819

To link to this article: http://dx.doi.org/10.1080/14786443908649819

册 Published online: 01 Jun 2009.

Submit your article to this journal 준

LII Article views: 2

Q View related articles $₫$ 
I employ two copper cylinders of the same height as that in the larger battery, and two wooden ones standing between the copper cylinders, a cylinder of zinc being placed between the former, by which means both surfaces of the zinc are opposed to surfaces of copper, and greatly increased power is obtained in the same space. This mode of arrangement, however, being somewhat more complicated and expensive, may not be approved of so much for general use, nor be employed except in cases where very powerful quantity effects are required.

In conclusion, I would add that $\frac{I}{4}$ th of the quantity of the solutions used in other batteries of the same extent of surface will suffice for those described, without any loss of power.

In the next Number of the Philosophical Magazine, I hope to be able to make some observations upon the proper proportions of zinc and copper in voltaic combinations, and in reference to the investigations of Mr. Binks upon the same subject, which have much interested me.

Cheltenham, June 2, 1839.

VIII. A Geometrical Proposition. By JamesT Homson, $L L . D .$, Professor of Mathematics in the University of Glasgow.

To the Editors of the Philosophical Magazine and Journal. Gentlemen,

T SHALL feel obliged by your inserting in your Magazine 1 the following proposition, which I believe to be new, and which is certainly curious.

Glasgow College, June 10, 1839.

James Thomson.

Let $\mathrm{A} \mathrm{BC}$ be a plane triangle, and through any point $\mathrm{P}$ in its plane, let A D, B E, C F, be drawn, cutting the sides,

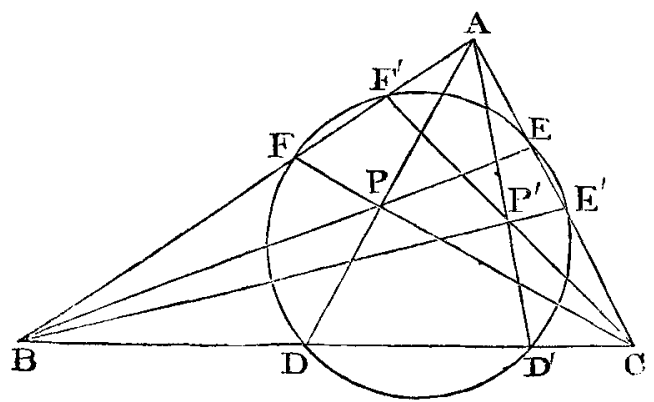

or the sides produced, in $\mathrm{D}, \mathrm{E}, \mathrm{F}$ : through $\mathrm{D}, \mathrm{E}, \mathrm{F}$ describe a circle cutting the sides, or the sides produced, in $\mathrm{D}^{\prime}, \mathbf{E}^{\prime}, \mathrm{F}^{\prime}$ : join $\mathbf{A ~}^{\prime}, \mathbf{B} \mathbf{E}^{\prime}, \mathbf{C ~ F}^{\prime}$ : these lines all pass through a common point $\mathbf{P}^{\prime}$. 
42 Dr. T. Thomson on Pyroxylic Spirit and its Compounds.

For, by the theory of transversals, (Carnot, Essai sur la Théorie des Transversales, Théor. V.),

A F.BD.CE = F B.DC.EA.

But (Euc. III. 35. or 36.)
A $F=\frac{A E \cdot A E^{\prime}}{A F^{\prime}}$
$\mathrm{B} \mathrm{D}=\frac{\mathrm{B} \mathrm{F} \cdot \mathrm{B} \mathrm{F}^{\prime}}{\mathrm{B} \mathrm{D}^{\prime}}$, and $\mathrm{CE}=$
$\frac{\text { CD.CD' }}{\mathrm{C} \mathrm{E}^{\prime}}$

Substitute these in the first member of the preceding equation, and free the result of fractions: then, dividing by the quantities common to both members, we get

$$
A E^{\prime} \cdot B F^{\prime} \cdot C_{1} D^{\prime}=C E^{\prime} \cdot A F^{\prime} \cdot B D^{\prime} \text {. }
$$

Hence, by the theory of transversals, (Carnot, Essai sur la Théorie des Transversales, Théor. V.),

$A D^{\prime}, B E^{\prime}, C F^{\prime}$ all pass through the same point.

Cor. Hence, by supposing $\mathrm{D}$ and $\mathrm{D}^{\prime}, \mathrm{E}$ and $\mathrm{E}^{\prime}, \mathrm{F}$ and $\mathrm{F}^{\prime}$ to coincide, it follows, that the three straight lines drawn from the angles to the points in which the sides touch the inscribed circle, pass through the same point; and the same holds regarding the points of contact of any of the circles touching a side and the continuations of the other two.

Several curious questions and considerations, arising from this theorem, will naturally suggest themselves, particularly some regarding loci. I shall not, however, enter on such inquiries at present.

IX. On Pyroxylic Spirit and its Compounds. By Thomas Thomson, M.D., F.R.S., \&c. and Regius Professor of Chemistry in the University of Glasgore.**

DUMAS informs us that this remarkable substance was discovered by Mr. Philip Taylor in 1812, but that he did not make it known to the public till 1822 , in a letter to the Editors of the Philosophical Journal t. Never having seen this communication of Mr. Philip Taylor, I do not know the evidencef which he has brought forward in proof of his

* From his " Chemistry of Organic Bodies-Vegetables," p. 346.

$\dagger$ Chimie appliquée aux Arts, v. 492.

$\$$ [See L. \& E. Phil. Mag. vol. vii. p. 395, 427; vol. viii. p. 85 . If Dr. Thomson will refer to vol. ]x. p. 315. of the Phil. Mag. and Journal (for Oct. 1822), quoted by M. Dumas merely as the Philosophical Journal, he will find Mr. Philip 'Taylor's statement that this spirit was known to him in 1812; and some years before he published this account of it in 1822 , I had received a portion of it from him. I feel satisfied that Dr. Thomson must be in error as to dates when he mentions that he was in the habit of using it in 1816 ; I am certain that it was not emplcyed in London at that period, and what proves this almost to demonstration, is the following addition to Mr. Philip Taylor's announcement of his discovery: "I have sent Mr. Garden, of 372, Oxford-street, some of the pyrolig- 